\title{
Keragaan Usaha dan Nilai tambah Pada Agroindustri Keripik Tike (Studi Kasus di Desa Jumbleng Kecamatan Losarang Indramayu)
}

\author{
Endah Djuwendah, Lucyana Trimo dan Sonjanawati \\ Prodi Agibisnis Fakultas Pertanian Unpad \\ E-mail: endah.djuwendah@unpad.ac.id
}

\begin{abstract}
ABSTRAK
Keripik tike merupakan pangan lokal tradisional dari Kabupaten Indramayu yang berasal dari umbi tumbuhan Tike (Eleocharis dulcis Brumn f). Tike merupakan tumbuhan rawa pasang surut sulfat masam. Tanaman ini memiliki manfaat kesehatan karena mengandung Zat antibiotik puchiin dan vitamin C. Usaha pengolahan keripik tike memiliki peran penting dan potensial untuk dikembangkan karena mampu memberikan nilai tambah dari umbi tike menjadi komoditas pangan yang khas (local spesifik), memiliki cita rasa enak, bermanfaat bagi kesehatan, menciptakan kesempatan kerja dan memberikan pendapatan bagi masyarakat. Oleh karena itu cukup potensial untuk berkembang. Namun hingga saat ini usaha keripik tike belum berkembang secara luas karena terkendala oleh berbagai faktor diantaranya keterbatasan bahan baku, permodalan dan wilayah pemasaran. Tujuan penelitian ini adalah untuk menganalisis keragaan usaha dan nilai tambah agroindusti keripik tike yang berada di desa Jumbleng Kecamatan Losasang Kabupaten Indramayu. Metode penelitian yang digunakan adalah deskriptif kualitatif dengan teknis penelitiannya berupa studi kasus. Hasil penelitian menunjukkan bahwa pengadaan bahan baku umbi tike diperoleh dari Kabupaten Bekasi dan Cilacap dengan harga berkisar Rp 16.000 s,d 18.000 per Kg. Terjadi keterbatasan bahan baku tike saat peralihan dari musim kemarau ke musim penghujan. Tenga kerja yang digunakan berasal dari desa setempat dan berjumlah 2-6 orang per unit usaha dengan sistem upah harian. Modal penyedia bahan baku terdiri dari modal pribadi dan modal pinjaman. Pengolahan keripik tike melalui proses pencucian, perendaman, penyangraian, penumbukan, penjemuran, penggorengan dan pengemasan. Pemasaran Keripik tike dilakukan oleh pedagang perantara yaitu penyalur dan pengecer dengan harga jual berkisar Rp 2000 - 10,000 untuk pemasaran langsung kemasan kecil dan Rp 80.000 s.d 90.000/kg untuk pemasaran tidak langsung melalui penyalur. Wilayah pemawaran keripik tike umumnya di wilayah Kabupaten Indramayu dan Cirebon. Kapasitas produksi keripik tike rata-rata $50 \mathrm{~kg}$ umbi tike per proses produksi dengan tingkat konversi produk akhir mencapai 0,96. Nilai tambah per kilogam bahan baku adalah Rp 35.320, rasio nilai tambah 45,99\% dan keuntungan per nilai tambah adalah 30,36\%. Margin balas jasa terhadap faktor produksi paling besar dimiliki oleh keuntungan pengrajin yaitu 57,16\%, pendapatan tenaga kerja sebesar 29,41\% dan sisanya 13,43\% merupakan balas jasa terhadap sumbangan input lain.
\end{abstract}

Kata kunci: Keripik tike, keragaan usaha, nilai tambah 
Endah Djuwendah, Lucyana Trimo dan Sonjanawati

\section{ABSTRACT}

Tike Chips is a traditional local food from Indramayu Regency derived from tuber Tike (Eleocharis dulcis Brumn f). Tike is a sulphurous acid wet tidal swamp. This plant has health benefits because it contains Puchiin antibiotic and vitamin C. Tike chips processing business has an important role and potential to be developed because it can provide added value from tike bulb to be a specific local food commodity, has good taste, beneficial for health, creating employment opportunities and providing income for the community. It is therefore quite potential to develop. However, until now the business of tike chips has not developed widely due to constrained by various factors such as limited raw materials, capital and marketing area. The purpose of this research is to analyze business performance and value added agroindustry tike chips that located in Jumbleng Village, Subdistrict of Losasang of Indramayu Regency. The research method used is descriptive qualitative with technical research in the form of case study. The results of research shows that the procurement of tike tuber raw material is obtained from Bekasi and Cilacap regencies with prices ranging from Rp $16.000 \mathrm{~s}, \mathrm{~d} 18,000 \mathrm{per} \mathrm{kg}$. There is a limitation of tike raw materials during the transition from dry season to rainy season. Working tillers are from local villages and numbered of 2-6 people per business unit with daily wage system. Capital providers of raw materials consist of personal capital and loan capital. Processing of tike chips through washing process, immersion, roasted, collision, drying, frying and packaging. Marketing Chips tike is done by intermediary traders ie dealers and retailers with selling prices ranging from Rp 2000 - 10,000 for direct marketing of small packaging and Rp 80.000 s.d 90.000 / kg for indirect marketing through distributors. Tike chips offer areas generally in the districts of Indramayu and Cirebon. The production capacity of tike chips averages $50 \mathrm{~kg}$ of tike bulbs per production process with a final product conversion rate of 0.96. The added value per kilogram of raw materials is $R p$ 35,320, the value added ratio is $45.99 \%$ and the profit per added value is $30.36 \%$. The greatest profit margin for the factor of production is owned by the craftsman's profit of $57.16 \%$, the employment income of $29.41 \%$ and the remaining $13.43 \%$ representing the remuneration to other input contributions.

Keywords: Tike chips, business performance, added value 


\section{PENDAHULUAN}

Indonesia memiliki banyak potensi pangan lokal dari berbagai jenis umbi-umbian. Pemanfaatan umbi-umbian lokal merupakan alternatif sumber karbohidrat, protein dan vitamin yang murah dan dapat terjangkau oleh masyarakat. Namun demikian, potensi keanekaragaman jenis umbi-umbian yang ada di Indonesia saat ini masih belum banyak dimanfaatkan secara optimal.

Umbi tike adalah salah satu umbi-umbian yang dapat dimanfaatkan sebagai pangan khas lokal. Tumbuhan tike mempunyai banyak manfaat diantaranya adalah air perasan umbinya mengandung zat anti biotik puchiin yang efektif melawan Staphylococcus aureus, Escherichia coli, Aerobacter aerogenes dan mengandung banyak vitamin $\mathrm{C}$ untuk kesehatan kulit. Keberadaanya di China, Indo-China dan Thailand dimanfaatkan sebagai sayuran mentah dan bahan olahan seperti campuran omelet, sayur berkuah, campuran salad, dan campuran daging/ikan. Batang tikea dimanfaatkan sebagai bahan pembuatan tikar [1]. Menurut Chooi [2] kandungan gizi umbi tike terdiri dari air 77,30-78,30\%; protein 1,40-1,50\%; lemak 0,15-0,20\%; kanji 7-19\%, gula sukrosa 6,35\%; gula lain 1,94\%, serabut 0,80-0,90\%; mineral besi, fosforus, kalsium, dan vitamin C. Di Indonesia umbi tike dimanfaatkan untuk bahan kue dan bahan dasar pembuatan keripik tike di daerah Indramayu.

Keripik tike merupakan salah satu olahan pangan tradisional Indonesia yang berasal dari umbi tanaman tike. Menurut Dinas UKM perindustrian dan pedagangan Kabupaten Indramayu, industri keripik tike dikategorikan dalam usaha rumah tangga (home industry) dan industtri kecil yang tersentralisir di Desa Jumbleng Kecamatan Losarang. Warna keripik tike putih bercampur coklat kehitaman. Rasanya yang renyah dan gurih serta nilai gizi yang cukup tinggi ini telah menarik minat masyarakat untuk mengkonsumsinya. Terdapat 51 orang pengrajin keripik tike di Desa Jumbleng dan keripik tike yang diproduksinya diperkirakan mencapai 100 ton. Pengolahan keripik tike tidak menghasilkan limbah yang mencemari lingkungan hanya berupa sisa akar dan tanah yang dibuang ke selokan atau kolam ikan.

Usaha keripik tike di Desa Jumbleng sudah berlangsung sejak tahun 1970. Dalam perkembangannya usaha ini menghadapi beberapa kendala diantaranya keterbatasan dalam memenuhi bahan baku umbi tike pada saat musim hujan sehingga menjadi home Industry musiman di Desa Jumbleng. Permasalahan lain diantaranya terkait belum terkondisikannya usaha industri setempat dikarenakan tidak ada lembaga hukum seperti koperasi atau badan usaha yang mengatur kebijakan usaha ditempat yang kemudian menyebabkan terjadinya persaingan antar pengusaha yang tidak sehat dalam penentuan harga jual dan pendistribusian produksi ke lokasi pasar. Meskipun industri keripik tike sudah mampu memasarkan produksinya diluar wilayah Kabupaten Indramayu, namun pengusaha keripik tike tidak menyertakan label atau cap sebagai salah satu bentuk promosi dalam memperkenalkan asal produk tersebut. sistem pemasaran maupun persaingan yang terjadi diantara pengusaha setempat Hal ini akan mempengaruhi keberlanjutan usaha keripik tike [3].

Permasalahan yang dihadapi oleh usaha keripik tike ini sejalan dengan permasalahan yang dihadapi oleh Usaha Mikro Kecil dan Menengah (UMKM) lainnya. Menurut Tambunan [4], pengembangan industri rumah tanga, kecil dan mikro tidak selamanya berjalan dengan lancar, terdapat beberapa kendala yang dihadapi diantaranya keterbatasan modal, kesulitan dalam mendapatkan bahan baku, keterbatasan teknologi dan sumberdaya manusia yang baik serta kesulitan dalam pemasaran.

Walaupun usaha keripik tike memiliki beberapa kendala, namun usaha ini terus bertahan di Desa Jumbleng dan produksinya sendiri memiliki peluang usaha yang cukup besar bagi para pelakunya karena pengolahannya yangsederhana menggunakan teknologi tradisional, permintaan konsumen yang besar walaupun memiliki harga jual berkisar Rp 75.000 s.d 90.000 per kilogram.

Agroindustri keripik tike memiliki peran penting karena mampu memberikan nilai tambah yang lebih tinggi pada umbi tike sehingga memiliki bentuk, warna dan rasa yang menarik sebagai salah satu upaya penganekaragaman pangan lokal, sumber penghasilan dan meningkatkan kondisi sosial 
ekonomi pengusaha keripik tike dalam memenuhi kebutuhan hidupnya. Oleh karena itu usaha ini memiliki prospek untuk terus berkembang.

Adapun tujuan penelitian ini adalah untuk (1) menganalisis keragaan usaha agroindustri keripik tike dan (2) menganalisis besarnya nilai tambah agroindustri tike yang berada di Desa jumbleng kecamatan: Losarang Kabupaten Indaramayu.

\section{METODE PENELITIAN}

Desain penelitian yang digunakan berupa penelitian kualitatif. Menurut Kresno dalam Lapaua [5], desain penelitian kualitatif adalah jenis penelitian yang secara khusus menggunakan teknis untuk memperoleh jawaban atau informasi mendalam tentang pendapat, persepsi dan perasaan seserorang sehingga mungkin mendapatkan hal-hal yang tersiat mengenai sikap, kepercayaan, motivasi dan perilaku subyek yang diteliti melalui informan. Metode atau teknis penelitian yang digunakan adalah studi kasus. Studi kasus merupakan bagian dari metode kualitatif yang hendak mendalami suatu kasus tertentu secara lebih mendalam yang melibatkan pengumpulan berbagai sumber informasi [6]. Lokasi penelitian dipilih secara sengaja di Desa Jumbleng Kecamatan Losarang Kabupaten Indramayu yang merupakan sentra industri rumah tangga keripik Tike.

Jenis dan sumber data yang digunakan adalah data primer dan sekunder. Teknis pengumpulan data dilakukan dengan cara wawancara, observasi, dokumentasi dan trianggulasi. Informan terdiri dari 7 orang pengrajin keripik tike, aparat desa Jumbleng, kepala dinas perindusttrian kabupaten Indramayu dan penyedia bahan baku keripik tike. Analisis data menggunakan teknis analisis nilai tambah dengan Metode Hayami. Formulasi analisis nilai tambah dapat dilihat pada Tabel 1. Selanjutnya Data yang telah didapat disajikan secara deskriptif, melalui proses reduksi data, pemaparan data dan penarikan kesimpulan.

Tabel 1. Metode Analisis Nilai Tambah dalam Agroindustri

\begin{tabular}{|c|c|c|}
\hline No. & Keterangan & Rumus Perhitungan \\
\hline \multicolumn{3}{|c|}{ I. INPUT, OUTPUT DAN HARGA } \\
\hline 1. & Output (kg/proses) & 1 \\
\hline 2. & Input (kg/proses) & 2 \\
\hline 3. & Tenaga Kerja (HOK/proses) & 3 \\
\hline 4. & Faktor Konversi & $1: 2$ \\
\hline 5. & Koefisien Tenaga Kerja & $3: 2$ \\
\hline 6. & Harga Output $(\mathrm{Rp} / \mathrm{kg})$ & 6 \\
\hline 7. & Upah rata-rata $(\mathrm{Rp} / \mathrm{kg})$ & 7 \\
\hline \multicolumn{3}{|c|}{ II. NILAI TAMBAH DAN KEUNTUNGAN } \\
\hline 8. & Harga Input (Rp/kg) & 8 \\
\hline 9. & Nilai Input Lain $(\mathrm{Rp} / \mathrm{kg})$ & 9 \\
\hline 10. & Nilai Output $(\mathrm{Rp} / \mathrm{kg})$ & $4 \times 6$ \\
\hline \multirow[t]{2}{*}{11.} & a. Nilai Tambah $(\mathrm{Rp} / \mathrm{kg})$ & $10-8-9$ \\
\hline & b. Rasio Nilai Tambah (\%) & 11a: 10 \\
\hline \multirow[t]{2}{*}{12.} & a. Imbalan Tenaga Kerja $(\mathrm{Rp} / \mathrm{kg})$ & $5 \times 7$ \\
\hline & b. Rasio Nilai Tambah (\%) & $12 \mathrm{a}: 11 \mathrm{a}$ \\
\hline \multirow[t]{2}{*}{13.} & a. Keuntungan $(\mathrm{Rp} / \mathrm{kg})$ & $11 \mathrm{a}-12 \mathrm{a}$ \\
\hline & b. Tingkat Keuntungan (\%) & $13 \mathrm{a}: 11 \mathrm{a}$ \\
\hline \multicolumn{3}{|c|}{$\begin{array}{l}\text { III. BALAS JASA FAKTOR PRODUKSI } \\
\end{array}$} \\
\hline \multirow[t]{4}{*}{14.} & Marjin & $10-8$ \\
\hline & a. Pendapatan Tenaga Kerja (\%) & $12 \mathrm{a}: 14$ \\
\hline & b. Sumbangan Input Lain (\%) & $9: 14$ \\
\hline & c. Keuntungan Pengolah (\%) & $13 \mathrm{a}: 14$ \\
\hline
\end{tabular}

Sumber: Hayami, 1987 dalam Hasanah [7]. 


\section{HASIL DAN PEMBAHASAN}

\subsection{Keragaan Usaha Keripik Tike di Desa Jumbleng Kecamatan Losarang}

Keragaan usaha adalah segala kegiatan yang berkaitan dengan agroindustri keripik tike, terutama dalam subsistem pengolahan hasil yaitu mengolah umbi tike menjadi keripik tike. Aktivitas utama dalam kegiatan operasional agroindustri antara lain pengadaaan sarana produksi, proses produksi dan pemasaran.

Pemanfaatan tumbuhan tike oleh masyarakat Desa Jumbleng sebagai bahan olahan pangan sudah berlangsung sekitar 50 tahun yang lalu dalam bentuk penggunaan umbi tike sebagai pengganti nasi dan daun tumbuhan tike sebagai olahan sayuran. Pada tahun 1970 umbi tike yang sebelumnya hanya direbus mulai diolah menjadi keripik, setelah masyarakat melihat proses pembuatan emping melinjo sentra produksi emping melinjo yang berada di daerah Karangampel. Proses pengolahan keripik tike mirip dengan proses pengolahan emping melinjo yaitu melalui proses pencucian, penyangraian, penumbukan, penjemuran dan pengorengan.

\subsection{Penyediaan Sarana Produksi Umbi Tike}

Sarana produksi berupa bahan baku umbi tike, bahan penunjang berupa bahan bakar, bumbu dan tenaga kerja manusia. Tumbuhan tike tumbuh liar di daerah rawa dan tegalan yang dipenuhi air, umumnya lahan tersebut berada di dekat pantai. Dulu tumbuhan tike banyak ditemukan di desa Jumbleng, Desa Bangkalan, Desa Krangkeng, Desa Caplek dan desa lainnya di Indramayu. Umbi tike yang dihasilkan dari Indramayu memiliki rasa khas, lebih manis ketika diolah. Namun seiring dengan alih fungsi lahan menjadi kolam air tawar dan pemukiman. Tumbuhan tike di Desa Jumbleng sulit ditemukan. Saat ini umbi tike diperoleh dari desa Panikel Kecamatan Karangwetan dan Kecamatan Kampung laut di Kabupaten Cilacap serta Pantai Harapan Jaya Kecamatan Muara Gembong Kota Bekasi [8].

Pengrajin keripik tike mendapat pasokan umbi tike dari 5 orang pedagang besar yang bekerjasama dengan 15 pedagang pengumpul umbi tike dari wilayah Muara Gembong Bekasi dan 2 pedagang pengumpul umbi tike dari Kabupaten Cilacap Jawa tengah. Harga bahan baku yang dijual oleh pedagang pengumpul umbi tike Rp.7.500/liter $(1 / 2 \mathrm{~kg})$ untuk umbi tike dari Muara Gembong dan Rp.6.000/liter (1/2 kg) umbi tike Cilacap.

Tabel 2. Intensitas Pasokan Umbi Tike per bulan dari Penyedia Bahan Baku .

\begin{tabular}{ccccccccccccc}
\hline \multirow{2}{*}{ Asal Umbi Tike } & \multicolumn{10}{c}{ Kuantitas Umbi Tike/Bulan } \\
\cline { 2 - 12 } & 1 & 2 & 3 & 4 & 5 & 6 & 7 & 8 & 9 & 10 & 11 & 12 \\
\hline $\begin{array}{c}\text { Umbi Tike Muara Gembong } \\
\text { Umbi Tike Cilacap }\end{array}$ & 0 & 0 & 0 & 1 & 2 & 2 & 3 & 3 & 2 & 1 & 0 & 0 \\
\hline
\end{tabular}

Keterangan:

a. Angka 1 menunjukan umbi tike yang didapatkan sedikit 500-1000 liter dengan intensitas pengambilan tiga hari sekali dalam satu bulan

b. Angka 2 menunjukan umbi tike yang didapatkan sedang/normal 1500 liter dengan intensitas pengambilan empat kali dalam satu bulan

c. Angka 3 menunjukan umbi tike yang didapatkan banyak 2000-3000 liter dengan intensitas pengambilan 6-8 kali dalam satu bulan.

Berdasarkan Tabel 2, diketahui bahwa pengadaan umbi tike dengan intensitas sedikit terjadi pada bulan April dan Oktober dan Intensitas banyak terjadi pada bulan Juli dan Agustus. Umbi tike yang didapatkan pengrajin keripik tike jumlahnya tidak tetap, paling banyak sekitar 100-200 rantang, dan paling sedikit mencapai 10-40 rantang.

Penyedia bahan baku menjual umbi tike kepada pengrajin keripik tike dengan harga Rp. 16.000/rantang untuk umbi tike Cilacap, dan Rp.18.000/rantang untuk umbi tike Jakarta/ Muara Gembong. Satu rantang sekitar $0,5 \mathrm{~kg}$. Pembayaran umbi tike oleh pengrajin kepada penyedia bahan baku terjadi secara tunai atau kredit. 
Perbedaan harga terjadi karena umbi tike Muara gembong lebih bagus, rasanya lebih manis warna kulitnya merah. Jumlah umbi tike dari Muara gembong Bekasi lebih sedikit daripada umbi tike Cilacap. Namun dalam segi kuantitas umbi tike Cilacap lebih banyak dibandingkan dengan umbi tike dari Muara gembong.

Keterbatasan bahan baku tike terjadi saat peralihan dari musim kemarau ke musim penghujan. Kandungan zat pati umbi tike pada masa ini sedikit dan ketika diolah hancur. Selain itu pada musim hujan air laut naik, dan jika tumbuhan tike terendam air laut kualitas umbinya tidak bagus. Pada saat musim hujan, lahan rawa yang ditumbuhi tumbuhan tike tergenang oleh air laut yang pasang. Air laut menyebabkan umbi tike yang dihasilkan menjadi berair dan bertekstur lembek, sehingga tidak bisa diolah.

\subsection{Penyediaan sarana produksi Tenaga kerja}

Tabel 3. Tenaga Kerja Agroindustry Keripik Tike.

\begin{tabular}{lccc}
\hline \multirow{2}{*}{ Jenis pekerjaan } & \multicolumn{3}{c}{ Kriteria tenaga kerja yang diperlukan } \\
\cline { 2 - 4 } & Jumlah (orang) & Jenis kelamin & Upah (Rp/satuan) \\
\hline Buruh cuci & & Laki-laki & $2000 / \mathrm{kg}$ \\
\hline Buruh tumbuk & $2-6$ & Perempuan dan laki-laki & $10.000 / \mathrm{kg}$ \\
\hline Buruh kupas & & Perempuan dan laki-laki & $12.000 / \mathrm{kg}$ \\
\hline
\end{tabular}

Penggunaan tenaga kerja dalam usaha keripik tike kebanyakan adalah wanita yang berasal dari desa setempat. Pada aktifitas mencuci umbi tike digunakan tenaga kerja laki-laki dan aktifitas menumpuk tike digunakan tenaga kerja perempuan. Upah tenaga kerja berupa harian lepas artinya dibayar langsung oleh pengrajin keripik tike ketika pekerja selesai dengan pekerjaanya. Buruh yang sudah ahli bisa menumbuk $5 \mathrm{~kg}$ tike basah dengan upah 50 ribu per hari.

Pada saat musim tanam padi, pengrajin mengalami kesulitan mencari tenaga kerja. Banyak diantara tenaga kerja yang biasa bekerja mengolah umbi tike beralih profesi menjadi buruh tanam padi, dikarenakan upah yang mereka dapat lebih besar yaitu Rp.100.000/hari.

\subsection{Penyediaan Modal}

Modal yang dibutuhkan oleh pengrajin dan penyedia bahan baku umbi tike berbeda. Sumber modal penyedia bahan baku berupa modal pribadi dan modal pinjaman. Modal pinjaman hanya dibutuhkan ketika jumlah umbi tike banyak yaitu mencapai $3000 \mathrm{~kg}$. Modal eksternal berasal dari bank swasta diantaranya BTPN. Modal yang harus disiapkan oleh penyedia bahan baku dalam satu kali pengiriman umbi tike Rp.18.800.000 ketika jumlah umbi tike mencapai $3000 \mathrm{~kg}$. Satu bulan terjadi $4 \mathrm{kali}$ pengiriman sehingga penyedia bahan baku harus menyiapkan modal sebesar Rp.150.400.000 per bulan. Sedangkan modal kerja yang diperlukan oleh pengrajin agroindustri keripik tike per proses produksi $(50 \mathrm{~kg})$ adalah $\mathrm{Rp} 2.674 .000$.

\subsection{Subsistem pengolahan hasil}

Rangkaian teknologi pengolahan keripik tike terbagi ke dalam 7 tahap pengolahan yaitu pencucian, perendaman, penyangraian, penumbukan, penjemuran, dan penggorengan alur proses pembuatan keriik tike disajikan pada Gambar 1. 


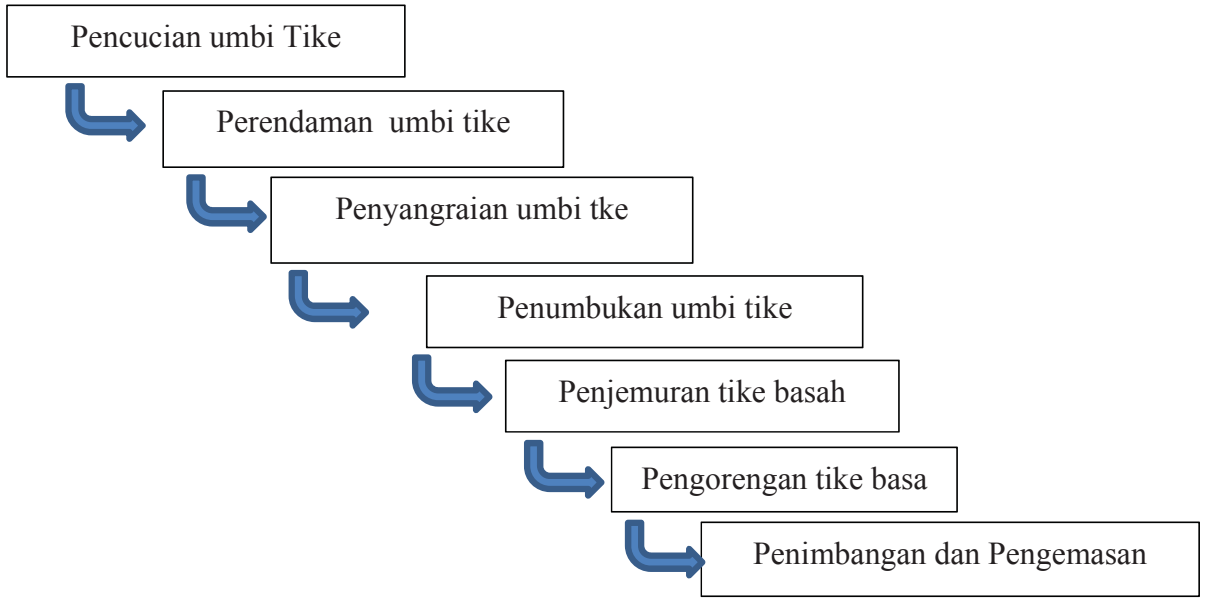

Gambar 1. Teknologi Pengolahan Keripik Tike

Umbi tike yang masih kotor dan berlumpur dimasukan dalam keranjang bambu (Wakul), lalu digilas menggunakan kaki sambil disiram air. Setelah bersih dari lumpur dan kotoran dilakukan pencucian kedua sambil dilakukan pengayakan untuk sortasi umbi tike yang baik dan yang rusak. Selanjutnya umbi yang sudah bersih direndam air selama 3-5 jam untuk menjaga tingkat kesegarannya. Air rendaman diganti setiap 5 jam dan umbi tike dapat bertahan sebelum diolah selama 5 hari.
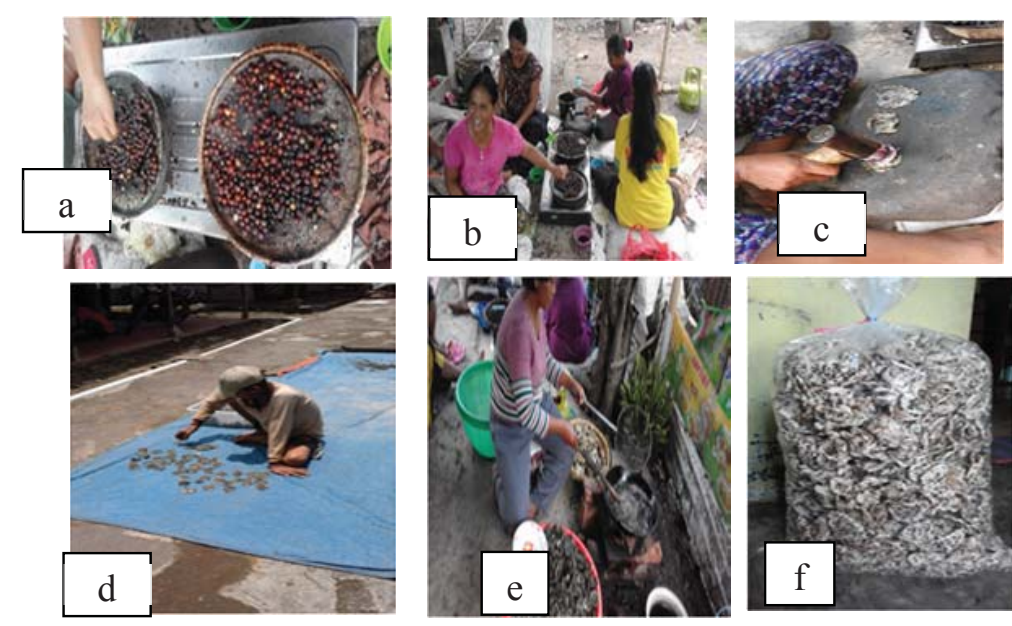

Gambar 2. Proses pengolahan kripik Tike; a) penyangraian umbi tike; b) penyangraian umbi tike; c) penumbukan umbi tike hingga pipih; d) tike basah sedang dijemur ; e) penggorengan kripik tike;

f) Kripik tike dalam kemasan besar (bal) siap utk dijual. Sumber: Sonjanawati [8].

Tahap berikutnya umbi tike disangrai di atas wajan datar panas yang sudah diolesi minyak goreng sampai kulit umbi menjadi matang (kulitnya kisut). Kulit luar dikupas lalu umbi tike matang ditumbuk menggunakan palu dan beralaskan batu. 3-4 umbi tikre ditumbuk bersamaan sehingga berbentuk pipih yang disebut tike basah. Penjemuran tike basah dilakukan selama 3 jam di bawah sinar matahari langsung saat musim panas. Apabila musim hujan tike basah diangin angin selama 2 hari di ruangan tertutup menggunakan bantuan kipas angin, setelah dijemur tike basah menjadi tike kering dengan kadar air berkurang sebesar $0,04 \mathrm{~kg}$. 
Tahap kelima adalah menggoreng tike kering dalam wajan besar yang berisi minyak goreng panas. Proses penggorengan berlangsung hingga keripik tike berwarna agak kecoklatan. Setelah digoreng keripik tike ditiriskan dan diberi bumbu racikan. Pengemasan dilakukan setelah keripik tike ditiriskan dan diberi bumbu. Kemasan yang dipakai berupa plastik tebal kapasitas $10 \mathrm{~kg}$ (bal) untuk penjualan ke luar daerah Indramayu dan plastik kecil ukuran 1 ons untuk penyalur keripik tike di wilayah lokal.

\subsection{Subsistem Pemasaran}

Subsistem pemasaran meliputi penanganan distribusi dan pemasaran hasil. Pemasaran Keripik tike dilakukan oleh perantara yaitu penyalur keripik tike dan pengecer besar. Terdapat 3 saluran pemasan keripik tike yaitu: (1) pengrajin $\rightarrow$ konsumen akhirt, (2) pengrajin $\rightarrow$ suplier $\rightarrow$ konsumen akhir dan (3) pengrajin $\rightarrow$ suplier s kecil $\rightarrow$ upplier besar $\rightarrow$ konsumen akhir.

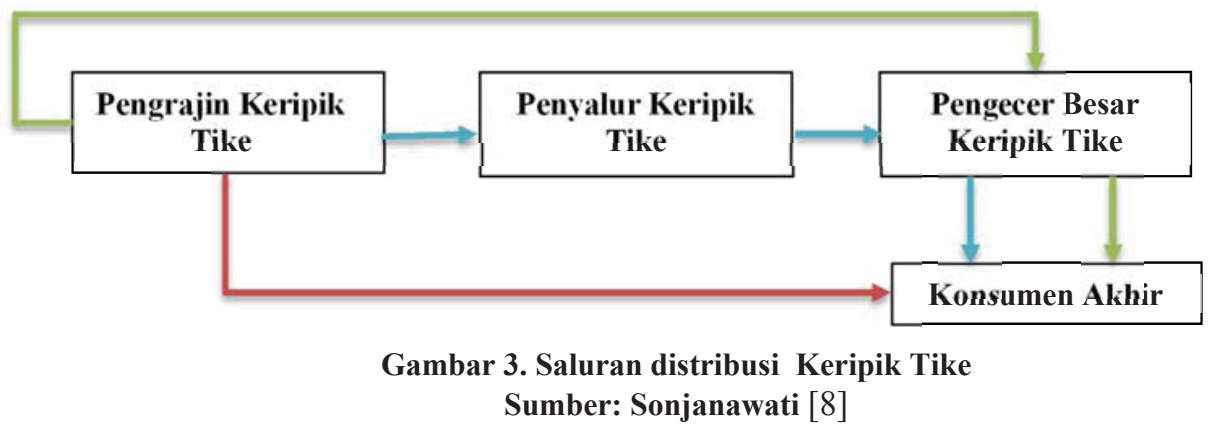

Harga jual kripik tike untuk pemasaran langsung dalam kemasan kecil berkisar Rp $2000-10,000$. Sedangkan harga jual kripik tike yang disalurkan melalui perantara berkisar antara Rp 70.000 s.d 90.000 per kg. Penyalur (suplier) keruipik tike melakukan perubahan kemasasn dan penambahan merek dagang, namun belum memiliki no IPRT dan sertifikat halal.

Wilayah pemasaran keripik tike terdapat di sekitar Kabupaten Indramayu dan Cirebon. Beberapa pengrajin ada yang mulai memasarkan menggunakan media internet secara on line melalui grup UMKM Indonesia, sehingga dapat memperluas pemasaran seperti pernah dilakukan transaksi ke Tangerang, Karawang dan Kalimantan.

\subsection{Subsistem Kelembagaan Penunjang}

Kelembangaan penunjang diperlukan bagi usaha keripik tike yang diharapkan dapat menjamin terciptanya integrasi dalam mewujudkan tujuan pengembangan usaha keripik tike. Kelembagaan pendukung tersebut diantaranya berupa kebijakan pemerintah melalui instrnai terkait seperti pembinaan UMKM dari dinas koperasi, perindustrian dan perdagangan, perbankan, kelompok usaha, penyuluh pertanian, litbang, dan media massa.

Menurut informasi dari kepala bidang Deperindag Kabupaten Indramayu, belum ada pembinaan secara intensidf terhadap para pangrajin keripik tike di wilayahnya. Walaupun pernah dilakukan pembinaan terkait dengan penyuluhan tentang pengemasan dan fasilitasi dalam pemberian label halal pada tahun 2012. Dukungan perbankan dalam pengadaan modal sudah mulai dirasakan oleh beberapa pengrajin. Kelompok usaha bersama juga sudah terbentuk yaitu Putri Harapan yang beranggota 32 orang pengrajin keripik tike. Menurut pengakuan salah satu anggota aktifitas dalam kelompok masih sangat terbatas, karena lemahnya koordinasi antara ketua dengan anggotanya, kelompok hanya berjalan saat mendapatkan bantuan peralatan dari dinas terkait.

Dukungan media komunikasi pada usaha keripik tike berupa liputan trans 7 dalam acara laptop si unyil yang mendokumentasikan dan menayangkan usaha keripik tike sebagai salah satu bentuk promosi usaha. Pemasaran on line juga dilakukan melalui situs tokopedia.com dan bulakapak.com. 


\subsection{Nilai Tambah Usaha Pengolahan Keripik Tike}

Kegiatan pengolahan umbi tike menjadi keripik tike akan memberikan nilai tabah yang cukup besar sehingga manfaat dari pengolahan tersebut dapat dinikmati oleh perusahaan, tenaga kerja dan konsumen yang menikmatinya. Menurut Hayami dkk [9], analisis nilai tambah pengolahan produk petanian dapat dilakukan dengan cara sederhana yaitu melalui perhitungan nilai tambah per kilogram bahan baku untuk satu kali proses produksi yang menghasilkan produk tertentu.

Secara sederhana nilai tambah agoindustri keripik tike dapat dihitung dari nilai penerimaan dikurangi dengan biaya bahan baku dan biaya input lainnya yang digunakan dalam pembuatan keripik tike. Analsisis nilai tambah menggunakan metode Hayami sepeerti tertetera pada Tabel 4 .

Tabel 4. Analisis Nilai tambah keripik Tike di desa Jumbleng Kecamatan Losarang

\begin{tabular}{clc}
\hline No & \multicolumn{1}{c}{ Variabel } & Nilai (per proses produksi \\
\hline I & Output, input dan Harga & 48 \\
\hline 1 & Output $(\mathrm{Kg})$ & 50 \\
\hline 2 & Bahan baku (kg) & 12 \\
\hline 3 & Tenaga kerja (HOK/proses produksi) & 0,96 \\
\hline 4 & Factor konversi & 0,24 \\
\hline 5 & Koefisien tenaga kerja langsung & 80.000 \\
\hline 6 & Harga Output (Rp/Kg) & 50.000 \\
\hline 7 & Upah rata-rata (Rp/HOK) & 36.000 \\
\hline II & Pendapatan dan keuntungan & 5.480 \\
\hline 8 & Harga bahan baku (Rp/kg BB) & 76.800 \\
\hline 9 & Sumbangan input lain (Rp/kg BB) & 35.320 \\
\hline 10 & Nilai outpout (Rp/kg BB) & 45,99 \\
\hline 11 & a. Nilai tambah (Rp/kg) & 12.000 \\
\hline & b. Rasio nilai tambah (\%) & 33,98 \\
\hline 12 & a. Imbalan tenaga kerja (Rp/kg BB) & 23.320 \\
\hline & b. Bagian tenaga kerja (\%) & 30,36 \\
\hline 13 & c. Keuntungan (Rp/kg) & \\
\hline & d. Tingkat keuntungan (\%) & 40.800 \\
\hline III & Balas jasa faktor produksi & 29,41 \\
\hline 14 & Margin (Rp/Kg) & 13,43 \\
\hline & a. Pendapatan tenaga kerja (\%) & 57,16 \\
\hline & b. Sumbangan input lain (\%)
\end{tabular}

Tabel 5 menginformasikan bahwa jumlah produksi rata-rata keripik tike per periode produksi adalah $48 \mathrm{~kg}$ dengan input bahan baku $50 \mathrm{Kg}$. Nilai tambah yang diperoleh agroindustry keripik tike setiap $1 \mathrm{~kg}$ bahan baku umbi tike menjadi keripik tike adalah Rp. 35.320. Sedangkan besarnya rasio nilai tambah yang dihasilkan per periode produksi adalah 45,99\%.

Produktivitas tenaga kerja dapat dilihat dari koefisien tenaga kerja. Agroindustri keripik tike memiliki koefisien tenaga kerjanya 0,24. Angka tersebut menujukkan satu kilogram bahan baku umbi tike diolah sampai menjadi keripik tike membutukan tenaga kerja 0,24 Hari Orang kerja (HOK). Imbalan tenaga kerja merupakan besarnya upah yang diberikan kepada tenaga kerja untuk memotivasi dan mempertahankan tenaga kerja dalam menjalankan usaha. Upah buruh berupa upah mencuci 2000/ kg dan menumbuk Rp 10.000/kg. Imbalan tenaga kerja adalah Rp 12.000/kg bahan baku atau Rp 50.000 per hari dengan kemampuan per orang tenaga kerja yang sudah terampil dalam menumbuk kritip tike maksimal $5 \mathrm{~kg} / \mathrm{hari}$.

Setiap agroindustri berusaha memperoleh keuntungan sebesar-besarnya, keuntungan diperoleh dari selisih nilai tambah dengan imbalan tenaga kerja. Rata-rata keuntungan agroindustry keripik tike adalah Rp.23 320 / kg bahan baku.

Margin merupakan selisih nilai outpout dengan harga bahan baku. Balas jasa terhadap faktor produksi tenaga kerja, sumbangan input lain dan keuntungan bisa terlihat dari margin tersebut. 
Margin usaha keripik tike sebesar Rp 40.800/kg bahan baku. Kontribusi margin terbesar dimiliki leh keuntungan pengrajin yaitu 57, 16\%, pendapatan tenga kerja dan 13,43\% untuk penggunaan input lainnya.

\section{KESIMPULAN}

1. Pengadaan bahan baku umbi tike diperoleh dari Kecamatan Karangwetan dan Kampung laut di Kabupaten Cilacap serta Pantai Harapan Jaya Kabupaten Bekasi dengan harga berkisar Rp $16.000 \mathrm{~s}, \mathrm{~d} 18.000$ per Kg. Terjadi keterbatasan bahan baku tike terjadi saat peralihan dari musim kemarau ke musim penghujan. Tenaga kerja yang digunakan berasal dari desa setempat dan berjumlah 2-6 orang per unit usaha dengan sistem upah harian. Tingkat upah berkisar 50 ribu per hari dengan kapasitas menumpuk $5 \mathrm{~kg}$ umbi tike per pekerja. Sumber modal penyedia bahan baku berupa modal pribadi dan modal pinjaman.

2. Terdapat tujuh tahap pengolahan keripik Tike yaitu pencucian, perendaman, penyangraian, penumbukan, penjemuran, penggorengan dan pengemasan. Pemasaran Keripik tike dilakukan oleh pedagang perantara yaitu penyalur dan pengecer. Terdapat 3 saluran pemasan keripik tike yaitu: (1) pengrajin $\rightarrow$ konsumen akhirt, (2) pengrajin $\rightarrow$ suplier $\rightarrow$ konsumen akhir dan (3) pengrajin $\rightarrow$ suppliers kecil $\rightarrow$ supplier besar $\rightarrow$ konsumen akhir. Harga jual kripik tike pada pemasaran langsung dengan kemasan kecil berkisar Rp 2000 - 10,000. Sedangkan harga jual melalui perantara berkisar Rp 80.000 s.d 90.000/kg. Penyalur (suplier) keripik tike melakukan perubahan kemasan dan penambahan merek dagang pada keripik tike namun belum memiliki no IPRT dan sertifikat halal. Wilayah pemawaran keripik tike sebagian besar terdapat di wilayah Kabupaten Indramayu dan Cirebon.

3. Kapasitas produksi agroindustri keripik tike rata-rata $50 \mathrm{~kg}$ umbi tike per proses produksi dengan tingkat konversi produk akhir mencapai 0,96. Nilai tambah per kilogam bahan baku adalah Rp 35.320 dan rasio nilai tambah sebesar 45,99\%. Keuntungan per nilai tambah yaitu sebesar 30,36 $\%$. Margin balas jasa terhadap faktor produksi paling besar dimilki oleh keuntungan pengrajin yaitu $57,16 \%$, pendapatan tenaga kerja sebesar $29,41 \%$ dan sisanya $13,43 \%$ merupakan balas jasa terhadap sumbangan input lain.

\section{DAFTAR PUSTAKA}

[1] Asikin S dan M Thamrin. 2012. Manfaat Purun Tikus(eleocharis dulcis)Pada Ekosistem Sawah Rawa. Jurnal Penelitian dan Pengembangan Pertanian Vol 31 no 1.

[2] Chooi, Ong Hean. 2003. Sayuran Khasiat Makanan \& Ubatan. Utusan Publication and Distributors Sdn Bhd. Kuala Lumpur.

[3] Maseha Santi. 2015. Hubungan Keberadaan Home Industri Keripik Tike dengan Kondisi Sosial Ekonomi Pengusaha Keripik Tike di Desa Jumbleng Kecamatan Losarang Kabupaten Indramayu. http://repository.upi.edu/17035/.

[4] Tambunan. 2002. Usaha Kecil dan Menengah di Indonesia Beberapa Isu Penting. Jakarta: Penebar Swadaya

[5] Lapaua Buchari. 2013. Metode Penelitian Kesehatan: Metode Ilmiah Penulisan Skripsi, Tesis, dan Disertasi. Pustaka Obor Indonesia. Jakarta.

[6] Semiawan, Conni R. 2010. Metode Penelitian Kualitatif: Jenis, Karakteristik dan Keunggulannya. PT Gamedia Widiasarana Indonesia. Jakarta.

[7] Hasanah, Uswatun, dkk. 2015. Analisis Nilai Tambah Agroindustri Sale Pisang di Kabupaten Kebumen, Jurnal Ilmu pertanian (Agricultural Science). Faperta UGM Vol 18 No 3. https://doi.org/10.22146/ipas.10615

[8] Sonjanawati, 2017. Kajian Faktor Pendorong dan Penghambat Pengembangan Home Industrty Keripik Tike. Prodi Agribisnis Faperta Unpad. Bandung

[9] Hayami, Kawagoe, Marooka, Siregar, 1987. Agricultural Marketing and Processing in Upland Java. A perspective from a sunda Village. CGPRT. Bogor. 